\title{
Information and Communication Technology in Indonesian Elementary Schools in Remote Areas
}

\author{
Ferril Irham Muzaki \\ Department of Primary Teacher \\ State University of Malang, Indonesia \\ ferril.irham.fip@um.ac.id
}

\author{
Achmad Supriyanto \\ Department of Educational Administration \\ State University of Malang, Indonesia \\ a.supriyanto.fip@um.ac.id
}

\begin{abstract}
The purpose of this study is to measure the achievement of IT-based learning in remote areas. The approach in this research uses ethnographic research with interview-based participatory observation method. The result of this research are: (1) the process of identity development and development process, although done to process the creation of an adequate learning development process; (2) the development of character values needs to be maintained in developing a character education process integrated with distance learning conducted by stakeholders; and (3) to develop the learning process in the network, learners are even involved in creating real work for the community. Suggested to the stakeholders for: (1) Development of learning in ICT-based network although developed based on the principle of independence and convenience; the process of developing ICT learning basically needs to be developed based on the needs of learners; and (2) the 21 st-century learning culture is a learning culture based on learning in the network. Development of learning in the network though reaching the whole region is no exception remote areas.
\end{abstract}

Keywords: information and communication technology, remote areas, network learning

\section{INTRODUCTION}

The principle of development of Information and Communication Technology (ICT) is the principle of infrastructure development, meaning that this development can touch various basic aspects such as skill development and behavioral skill. Anh, et al [1] argues skills for insightful archipelago along with the accompanying aspects. According to Vijay, et al [7] the ability and individual skills in dealing with change needs to be addressed as a major action in the development of a teacher's career process and the development of character education quality.

Another thing that needs to be developed is the ability of a teacher or student. In this aspect, the ability and skill of a learner become dominant as the rate of development of the times diminishes the independence and ability of an individual and the environment. In this case sit, the skills of an individual closely related to the ability of the individual to be able to adapt to the environment.

\section{METHODS}

This research uses ethnographic research method. The object of data collection is the Primary School located in East Java Indonesia, located in Tulungagung, Blitar, Malang, and Probolinggo areas both in the City and District.

This research uses participatory observation method, meaning to interview with elementary school age learners to take opinion about ICT in each region. The remote determination parameter is 15 kilometers from the center of the sub-district surrounded by rice fields and plantations.

\section{RESULTS AND DISCUSSION \\ IT Infrastructure on Elementary Schools in Remote Areas in Indonesia \\ Besides that, though claimed to have the ability in the field of self-management is beneficial in}

improving the quality of self and thinking organization owned by the learners. Tseng [6] argues that the development of character education, although based on the principle of promoting the development of communication and information technology.

This is in line with the view that independence and skills for designing information and communication technologies are needed in the process of developing the identity and insights of a learners' personality. Hillier [2] argues, the process of ICT development, although directed at the development of information and communication technology that leads to the development of skills in processing the information system is supported by the existence of data and facts that encourage the independence of an individual to learn.

Information and communication technology has become a basic necessity nowadays. Recently, various activities have been found that are helpful in developing educational activities in ICT-based primary schools. In elementary school activities, the existence of ICT infrastructure supports the economic activities of the community.

The points and points that are developed in ICT-based learning in elementary schools are the existence of infrastructure that supports ICT-based learning. Hillier [2] argues Information and Communication Technology Infrastructure Development in remote areas needs to be developed with satellite insight.

Development of ICT learning, of course, has a link with the development of integrated learning that occurred in elementary school. Salemink, et al [5] argues that the process of the formation of character education insight becomes important and strategic in the midst of the current turn of the era that requires the development of ideas and ideas. In this case, the development of ICT infrastructure although based on the formation of adequate Human Resources skills. 
With the development of ICT-based infrastructure, it is expected that the development of learning process activities will increase.

To develop information and communication technology, adequate capability development is required. On that basis, the infrastructure holds a fairly dominant role in developing the idea and structure of ICT development orientation. To develop the potential of ICT, then made the development of basic principles as adequate as the development of infrastructure networks and the development of satellite phones. Hillier [2] based on the opinion above, it is the necessary development of information and communication technology adequate. The development of satellite-based phones is needed to develop the potential of ICT.

To develop ICT, it is necessary to develop sufficient character education insights. It is on this basis that an infrastructure should be developed based on the principle that developing ideas requires adequate performance. In addition, infrastructure also plays an active role in developing human culture according to Salemink, et al [5]. In this case, the development of the ICT center is closely related to the development of an adequate information structure. Developing ICT cannot be separated from the development of acting skills in everyday life, in the elementary school environment.

\section{Mobile Learning for Elementary Schools in Remote Areas}

Mobile-based learning has never escaped the current topic of discussion. In the process of discussion based on Mobile learning, a learner despite having the ability and competence sufficient to create creativity in teaching and learning process. Mobile -based learning needs to be developed in primary schools that have information and communication technology (ICT) insights according to Patel, et al [4].

The development of national identity and nationalism is ensured from the equilibrium process. To develop this process, then an although taught the concept of information and communication technology since elementary school age. Furthermore, participants who attended elementary school despite developing proficiency in certain information processing fields. Learning Mobile learning development, an ICT learners although the principle of equality of access that learners in primary schools by Pattel, et al [4].

To promote teaching and learning process, a learner although taught to have enough understanding of the development of information and communication technology. This is a prerequisite for developing proficiency in the development of the ability to create further communication. Development of Games and various applications although done to attract learners of elementary school age in learning. In this development, it is necessary to develop an integrated learning process based on IT development.

\section{ICT Teaching in Elementary Schools on Remote} Areas

ICT-based learning elementary schools need to be developed to meet the intellectual vision of the 21st-century learning. Elementary schools despite developing ICT-based learning to build a sufficient diversity of knowledge for primary school level learners. Primary schools develop computers in the network (Daring) is useful for developing learners identity. In this case, ICT-based primary schools though able to develop science and communication technology and information devices according to Olayemi [3].

ICT-based Intelligent Schools require sufficient teaching materials and are able to work for the learning process. Knowledge of intelligence although developed to educate the life of nation and state adequate. ICT-based learning although based on the belief that the learning as a whole and consistent for the continuity of the learning process of ICT. In the process of developing intelligent school learning though designed to enlighten the thinking skills of primary school-age students.

The process of developing electronic-based learning needs to be developed to support the perception of character education nuances. Development of electronic nuanced learning although developed to adjust to digital-based learning. Skills and mastery of learning nuanced electronics need to be made to suit the development of science, technology and humanities are adequate. The development of the national identity, although carried out for the development process of adequate skills according to Patel, et al [4].

The process of developing ICT learning is humanistic despite being gained by developing an adequate identity and learning. In developing the process of ICT learning, of course, what is needed is the process of making the values of characters become dominant in line with the rate of development of digital information flow. In terms of developing ICT learning, it requires a harmonious learning atmosphere and touches the conscience of learners. Besides, the process of ICT learning is humanist although underlies every teacher in decision making.

The process of developing ICT-based 21stcentury digital literacy while focusing on the meaning that exists in self-development as well as digital organizations. In this case, the development of ICT learning, although focused on efforts to develop adequate learning variety. Development of learning identity in the development of scientific treasures although closely related to the skills to make the learning process easier. The development of ICToriented learning process has a major role in creating an adequate learning process according to Pattel, et al [4].

\section{CONCLUSION}

Development of ICT learning process in isolated areas despite focusing on social vulnerability loopholes. The process of making the identity of a nation despite developing ICT is used to build a sense of community identity.

ICT development in isolated areas despite the focus on basic skills and knowledge as a whole. The process of development of ICT in primary school 
isolated regions need to be focus on the development of adequate scientific ideas.

\section{REFERENCES}

[1] Anh, N. T., Vanfretti, L., Driesen, J., \& Van Hertem, D. 2015. A Quantitative Method to Determine ICT Delay Requirements for Wide-Area Power System Damping Controllers. IEEE Transactions on Power Systems, 30(4), 2023-2030.

[2] Hillier, M. 2018. Bridging the Digital Divide with OffLine e-Learning. Distance Education, 1-12.

[3] Olayemi, A. A. 2016. Alleviating Poverty among Nigeria Youth through ICT: A Case Study of Akure Ondo State, Nigeria. NG-Journal of Social Development, 417(3768), 1-6.

[4] Patel, P., \& Patel, N. 2017. ICT Pedagogy for Effective Learning, Education and Quality Evaluation. New York: Basic Books.

[5] Salemink, K., Strijker, D., \& Bosworth, G. 2017. Rural Development in the Digital Age: A Systematic Literature Review on Unequal ICT Availability, Adoption, and Use in Rural Areas. Journal of Rural Studies, 54, 360-371.

[6] Tseng, Y. M., \& Wu, C. C. 2018. Information and Communication Technology Learning between Parents and High School Students. World Academy of Science, Engineering and Technology. International Journal of Educational and Pedagogical Sciences, 5(5).

[7] Vijay, M., Bott, J., Fobi Nsutezo, S., Aiello, R. G., Carvalho Metanias Hallack, M., \& Aclan, C. 2017. How Information and Communications Technology (ICT) is Poised to Transform the Delivery of Energy Services. Retrieved January 1, 2018, from https://publications.iadb.org/handle/11319/8785?localeattribute $=e s \&$. 